\title{
Effect of Socioeconomic Status on Preeclampsia Cross Sectional Study
}

\author{
ALAA EL-DEEN A. YOUSSEF, M.D.*; MOSTAFA H. MOHAMED, M.D.*; \\ DINA M. EL-SAYED HABIB, M.D.* and SAMIA S.A. MOUSSA, M.Sc.** \\ The Department of Obstetrics and Gynecology, Faculty of Medicine, Assiut University* and Luxor General Hospital**, \\ Luxor, Egypt
}

\begin{abstract}
Background: Preeclampsia (PE) is defined as a pregnancy specific syndrome usually occurs after 20 week gestation, it is determined by increased blood pressure $(>140 \mathrm{mmHg}$ systolic or $>90 \mathrm{mmHg}$ diastolic) accompanied by proteinuria $(>0.3 \mathrm{gm}$ protein in a $24 \mathrm{~h}$ specimen). Preeclampsia is multifactorial disease with environmental, socioeconomic and seasonal influence. It also has genetic predisposition. Preeclampsia affects approximately 5 to $7 \%$ of all pregnancies. And it remains the major cause of maternal and fetal morbidity and mortality.
\end{abstract}

Aim of Study: Is detect the possible association between SES of the pregnant woman and PE and to assess whether the rate of PE or its severity is affected by different SES levels.

Patients and Methods: Cross sectional study design on pregnant women diagnosed to have preeclampsia at Luxor International Hospital. The purposive sample of 145 case collected through 6 months during the period from 1 st October 2016 until the end of April 2017. Sample size calculated using G power Program version 3.1.3 with Confidence Level (CL) $95 \%$. The study consist of 4 parts. 1 st part: A structure interviewing questionnaire was done for data collection; personal, medical, obestetrical. 2nd part: Clinical examination to diagnose PE. $3^{\text {rd }}$ part: Laboratory investigation to confirm diagnosis. 4th part: The SES data was designed according to modified Fahmy and El-Sherbini scale 2012 to asses the SES of the participating women which consist of 7 domains.

Results: The study resulted in no significant statistical difference between severity of preeclampsia and mother age $(p=0.800)$, obstetric history, previous history of PE $(p=0.075)$ and medical diseases such as essential hypertension $(p=0.300)$ and diabetes mellitus $(p=0.316)$; but there was a significant statistical relationship between severity of PE and bronchial asthma $(p=0.008)$. There is also a significant statistical relationship between severity of PE and level of education ( $p=$ $0.024)$, home sanitation $(p=0.014)$, family possessions ( $p=$ $0.0 .005)$, and economic status $(\mathrm{p}=0.030)$. but there is no significant statistical relationship between severity of PE and occupation $(p=0.111)$, family domain $(p=0.161)$ and health care domain $(\mathrm{p}=0.217)$.

Correspondence to: Dr. Alaa El-Deen A. Youssef,

The Department of Obstetrics and Gynecology, Faculty of Medicine, Assiut University
Conclusion: There is association between level of education, home sanitation, family possessions, and economic status as an indicators for socioeconomic status and severity of preeclampsia.

Recommendation: Health education programs should be organized for pregnant women about the risk factors of preeclampsia; and for staff members about risk factors, early detection and early management of preeclampsia; improving ante-natal care for pregnant mothers in Egypt and improve the health level of poor families to reduce the risks of preeclampsia and to help early diagnosis; so that can decrease maternal and perinatal mortality.

Key Words: Preeclampsia-Socioeconomic status.

\section{Introduction}

THE term socioeconomic status is used by sociologists to denote an individual or family's overall rank in the social and economic hierarchy [1]. The terms Socioeconomic Status (SES) are widely used in health research [2].

Socioeconomic Status (SES) usually refers to components of economic and social status that distinguish and characterize people [3]. While the relationship between SES and health has received increasing notice over the past 50 years, relatively little attention has been devoted to defining SES, validating existing definitions or evaluating existing measures. Lack of conceptual clarity and the bypassing of standard techniques have retarded the measurement of SES [4]. Indicators of SES are meant to reflect access to social and economic resources that may vary over time [5]. SES is usually measured by 3 variables: Education, occupation and income [6]

\section{Abbreviations}

SES: Socioeconomic Status.

PE : Preeclampsia. 
Preeclampsia is multifactorial disease with environmental, socioeconomic and seasonal influence [7]. There are several other risk factors associated with preeclampsia, these include: Obesity, multifetal gestation, maternal age and metabolic syndrome [8]

Preeclampsia affects approximately 5 to $7 \%$ of all pregnancies [9]. And it remains the major cause of maternal and fetal morbidity and mortality [10] The two main reasons of maternal death in preeclampsia are cerebral hemorrhage and adult respiratory distress syndrome [11]

Diagnostic criteria for severe preeclampsia include [12]:

- Systolic blood pressure >_ $160 \mathrm{mmHg}$.

- Diastolic blood pressure >_110mmHg.

- Pulmonary edema.

- Epigastric pain.

- Proteinuria; persistent $(2 \mathrm{gm} / 24 \text { hours or }\rangle_{-}+2$ dipstick).

- Progressive renal insufficiency and oliguria.

- Elevated liver enzymes.

- New onset cerebral or visual disturbance.

- Low platelets count $<100,000 / \mathrm{ml}$.

However, it is now appreciated that overt proteinuria may not be a feature in some women with the preeclampsia syndrome [13]

Regarding the fetus and neonate; preeclampsia is responsible for $5 \%$ of still births: $8-10 \%$ of the overall preterm birth rate, and for $15-20 \%$ of the overall fetal growth restriction and very low birth weight [14].

For women with preeclampsia, the mode of delivery should be determined by the fetal gestational age, fetal presentation, cervical status and maternal and fetal condition. Cesearean delivery is therefore not mandatory. Cervix ripening with induction of labor should be considered when possible after 32 weeks gestation. A $60 \%$ vaginal birth rate is achievable [15].

\section{Patients and Methods}

A cross-sectional study which was conducted in Obstetric and Gynecology Clinic and Department at Luxor International Hospital between October 2016 and April 2017. 145 women were accepted to participate in this study. They must be diagnosed to have preeclampsia (BP $>140 / 90 \mathrm{mmHg}+$ Proteinuria after 20 weeks gestation).

\section{All patients were evaluated by:}

A- Good personal, medical and obestetrical history must be taken from all cases. It include: Name, age, last menstrual period, parity, history of essential hyperten-sion, previous history of preeclampsia, history of other current medical illness and also we ask about headache and epigastric pain which is considered a symptoms of preeclampsia.

B- All cases will undergo clinical examination to search for signs of preeclampsia which include measuring of blood pressure and search for lower limb odema.

C- Laboratory investigations must be done to all cases to insure the diagnosis of preeclampsia. These laboratory investigation include detection of protein in urine, detection of serum uric acid, $\mathrm{CBC}$ and platelets count, liver function tests, renal function tests, abdominal U.S and non stress test.

D- Measuring of family socioeconomic status: Questionnaire is done according to the modified Fahmy and El-Sherbini SES scale to measure the score of the socioeconomic status of the family. The scale consist of 7 domains with total score 84, each domain contain many items that collectively it can measure the socioeconomic status of the family.

\section{Results}

Table (1) shows a statistical significance between age of the mother and SES $(p<0.001)$.

Table (2) shows the relationship between SES and duration of pregnancy; it shows statistical significance $(p=0.033)$. Table (3) shows the relationship between SES and obstetric history of cases; the relationship is not statistically significant.

Table (4) shows the relationship between SES and risk factors or medical diseases; it shows no statistical significant difference between SES and previous history of PE and medical diseases such as essential hypertension, diabetes mellitus and bronchial asthma.

Table (5) shows the relationship between severity of preeclampsia and mother age; the present study found that the rate of preeclampsia more common in younger age group especially those below age of 25 years old and the rate decline with increase of age; but this result was not a statistically significant. Table (6) shows a highly significant statistical relationship between severity of PE and duration of pregnancy $(p=0.000)$. 
Table (7) shows the relationship between severity of preeclampsia and obstetric history. It show no significant statistical relationship. Table (8) shows the relationship between severity of PE and risk factors or medical diseases. It show no statistical significant relationship between severity of $\mathrm{PE}$ in this pregnancy and previous history of PE and medical diseases such as essential hypertension and diabetes mellitus. But there is a significant statistical relationship between severity of PE and bronchial asthma $(p=0.008)$.

Table (9) shows no a statistical significant relationship between severity of preeclampsia and level of socioeconomic status.

Table (10) shows the relationship between domains of the SES and severity of PE. It shows significant statistical relationship between severity of PE and educational level of the parents ( $p=$ 0.024 ), preeclampsia is more severe in low educational group, while PE is mild with high educational group. Also it shows a significant statistical relationship between severity of preeclampsia and home sanitation domain $(p=0.014)$, preeclampsia is more severe in families with low sanitation. Also there is a significant statistical relationship between severity of preeclampsia and family possessions domain $(p=0.005)$ and economic domain $(p=0.030)$; we observed that preeclampsia is more severe in families with low income. Also there is a significant statistical relationship between severity of $\mathrm{PE}$ and total score of SES. There is no significant statistical relationship between severity of preeclampsia and occupation of the parents, family domain and health care domain.

Table (1): Relationship between socioeconomic status and mother age.

\begin{tabular}{lccccccccc}
\hline & \multicolumn{8}{c}{ Socioeconomic status } & \\
\cline { 2 - 8 } $\begin{array}{l}\text { Age } \\
\text { (years })\end{array}$ & $\begin{array}{c}\text { Very low } \\
(\mathrm{n}=34)\end{array}$ & \multicolumn{2}{c}{$\begin{array}{c}\text { Low } \\
(\mathrm{n}=36)\end{array}$} & $\begin{array}{c}\text { Middle } \\
(\mathrm{n}=38)\end{array}$ & $\begin{array}{c}\text { High } \\
(\mathrm{n}=37)\end{array}$ & \multirow{2}{*}{$p$-value } \\
\cline { 2 - 9 } & No. & $\%$ & No. & $\%$ & No. & $\%$ & No. & $\%$ & \\
\hline$<25$ & 25 & 73.5 & 22 & 61.1 & 17 & 44.7 & 7 & 18.9 & $<0.001^{*}$ \\
$25-<30$ & 3 & 8.8 & 10 & 27.8 & 15 & 39.5 & 25 & 67.6 & \\
$\geq 30$ & 6 & 17.6 & 4 & 11.1 & 6 & 15.8 & 5 & 13.5 & \\
\hline
\end{tabular}

Table (2): Relationship between socioeconomic status and duration of pregnancy.

\begin{tabular}{|c|c|c|c|c|c|c|c|c|c|}
\hline \multirow{3}{*}{$\begin{array}{l}\text { Duration } \\
\text { of } \\
\text { pregnancy }\end{array}$} & \multicolumn{8}{|c|}{ Socioeconomic status } & \multirow{3}{*}{$p$-value } \\
\hline & \multicolumn{2}{|c|}{$\begin{array}{l}\text { Very low } \\
(n=34)\end{array}$} & \multicolumn{2}{|c|}{$\begin{array}{c}\text { Low } \\
(\mathrm{n}=36)\end{array}$} & \multicolumn{2}{|c|}{$\begin{array}{l}\text { Middle } \\
(\mathrm{n}=38)\end{array}$} & \multicolumn{2}{|c|}{$\begin{array}{l}\text { High } \\
(\mathrm{n}=37)\end{array}$} & \\
\hline & No. & $\%$ & No. & $\%$ & No. & $\%$ & No. & $\%$ & \\
\hline$<34$ & 13 & 38.2 & 18 & 50.0 & 11 & 28.9 & 5 & 13.5 & $0.033 *$ \\
\hline $34-36$ & 11 & 32.4 & 7 & 19.4 & 9 & 23.7 & 14 & 37.8 & \\
\hline$>30$ & 10 & 29.4 & 11 & 30.6 & 18 & 47.4 & 18 & 48.6 & \\
\hline
\end{tabular}

Table (3): Relationship between socioeconomic status and obstetric history.

\begin{tabular}{|c|c|c|c|c|c|c|c|c|c|}
\hline & \multicolumn{8}{|c|}{ Socioeconomic status } & \multirow{3}{*}{$p$-value } \\
\hline & \multicolumn{2}{|c|}{$\begin{array}{l}\text { Very low } \\
(\mathrm{n}=34)\end{array}$} & \multicolumn{2}{|c|}{$\begin{array}{c}\text { Low } \\
(\mathrm{n}=36)\end{array}$} & \multicolumn{2}{|c|}{$\begin{array}{l}\text { Middle } \\
(\mathrm{n}=38)\end{array}$} & \multicolumn{2}{|c|}{$\begin{array}{l}\text { High } \\
(\mathrm{n}=37)\end{array}$} & \\
\hline & No. & $\%$ & No. & $\%$ & No. & $\%$ & No. & $\%$ & \\
\hline \multicolumn{10}{|l|}{ Gravidity: } \\
\hline Primigravida & 23 & 67.6 & 23 & 63.9 & 19 & 50.0 & 22 & 59.5 & 0.469 \\
\hline $2-3$ & 5 & 14.7 & 7 & 19.4 & 9 & 23.7 & 11 & 29.7 & \\
\hline$>3$ & 6 & 17.6 & 6 & 16.7 & 10 & 26.3 & 4 & 10.8 & \\
\hline \multicolumn{10}{|l|}{ Parity: } \\
\hline Nullipara & 23 & 67.6 & 23 & 63.9 & 19 & 50.0 & 22 & 59.5 & 0.168 \\
\hline $1-2$ & 6 & 17.6 & 8 & 22.2 & 11 & 28.9 & 14 & 37.8 & \\
\hline$>2$ & 5 & 14.7 & 5 & 13.9 & 8 & 21.1 & 1 & 2.7 & \\
\hline \multicolumn{10}{|l|}{ Abortion: } \\
\hline No abortion & 31 & 91.2 & 32 & 88.9 & 31 & 81.6 & 32 & 86.5 & 0.654 \\
\hline Abortion & 3 & 8.8 & 4 & 11.1 & 7 & 18.4 & 5 & 13.5 & \\
\hline
\end{tabular}


Table (4): Relationship between socioeconomic status and risk factors.

\begin{tabular}{|c|c|c|c|c|c|c|c|c|c|}
\hline \multirow{3}{*}{ Risk factors } & \multicolumn{8}{|c|}{ Socioeconomic status } & \multirow{3}{*}{$p$-value } \\
\hline & \multicolumn{2}{|c|}{$\begin{array}{l}\text { Very low } \\
(n=34)\end{array}$} & \multicolumn{2}{|c|}{$\begin{array}{c}\text { Low } \\
(n=36)\end{array}$} & \multicolumn{2}{|c|}{$\begin{array}{l}\text { Middle } \\
(\mathrm{n}=38)\end{array}$} & \multicolumn{2}{|c|}{$\begin{array}{l}\text { High } \\
(n=37)\end{array}$} & \\
\hline & No. & $\%$ & No. & $\%$ & No. & $\%$ & No. & $\%$ & \\
\hline \multicolumn{10}{|c|}{ H. of essential HTN: } \\
\hline Yes & 1 & 2.9 & 1 & 2.8 & 2 & 5.3 & 0 & 0.0 & 0.584 \\
\hline No & 33 & 97.1 & 35 & 97.2 & 36 & 94.7 & 37 & 100.0 & \\
\hline \multicolumn{10}{|c|}{ P.H. of preeclampsia: } \\
\hline Yes & 4 & 11.8 & 5 & 13.9 & 5 & 13.2 & 5 & 13.5 & 0.994 \\
\hline No & 30 & 88.2 & 31 & 86.1 & 33 & 86.8 & 32 & 86.5 & \\
\hline \multicolumn{10}{|l|}{ H. of $D M$ : } \\
\hline Yes & 3 & 8.8 & 1 & 2.8 & 2 & 5.3 & 3 & 8.1 & 0.702 \\
\hline No & 31 & 91.2 & 35 & 97.2 & 36 & 94.7 & 34 & 91.9 & \\
\hline \multicolumn{10}{|c|}{ H. of bronchial asthma: } \\
\hline Yes & 3 & 8.8 & 1 & 2.8 & 1 & 2.6 & 0 & 0.0 & 0.222 \\
\hline No & 31 & 91.2 & 35 & 97.2 & 37 & 97.4 & 37 & 100.0 & \\
\hline
\end{tabular}

Table (5): Relationship between severity of preeclampsia and mother age.

\begin{tabular}{|c|c|c|c|c|c|}
\hline \multirow{3}{*}{$\begin{array}{l}\text { Age } \\
\text { (years) }\end{array}$} & \multicolumn{4}{|c|}{ Severity of preeclampsia } & \multirow{3}{*}{$\begin{array}{c}p \text { - } \\
\text { value }\end{array}$} \\
\hline & \multicolumn{2}{|c|}{ Mild (n=88) } & \multicolumn{2}{|c|}{ Severe $(n=57)$} & \\
\hline & No. & $\%$ & No. & $\%$ & \\
\hline$<25$ & 42 & 59.2 & 29 & 40.8 & 0.800 \\
\hline $25-<30$ & 34 & 64.2 & 19 & 35.8 & \\
\hline$\geq 30$ & 12 & 57.1 & 9 & 42.9 & \\
\hline
\end{tabular}

Table (7): Relationship between severity of preeclampsia and obstetric history.
Table (6): Relationship between severity of preeclampsia and duration of pregnancy.

\begin{tabular}{llccccc}
\hline \multirow{2}{*}{$\begin{array}{l}\text { Duration } \\
\text { of } \\
\text { pregnancy }\end{array}$} & \multicolumn{3}{c}{ Severity of preeclampsia } & \\
\cline { 2 - 3 } & \multicolumn{2}{c}{ Mild $(\mathrm{n}=88)$} & & \multicolumn{2}{c}{ Severe $(\mathrm{n}=57)$} & $\begin{array}{c}p \text { - } \\
\text { value }\end{array}$ \\
\cline { 2 - 3 } & No. & $\%$ & & No. & $\%$ & \\
\hline$<34$ & 6 & 12.8 & & 41 & 87.2 & $0.000^{*}$ \\
$34-36$ & 29 & 70.7 & & 12 & 29.3 & \\
$>36$ & 53 & 93.0 & 4 & 7.0 & \\
\hline
\end{tabular}

Table (8): Relationship between severity of preeclampsia and risk factors.

\begin{tabular}{|c|c|c|c|c|c|c|c|c|c|c|c|}
\hline & \multicolumn{4}{|c|}{ Severity of preeclampsia } & \multirow{3}{*}{$\begin{array}{c}p- \\
\text { value }\end{array}$} & \multirow{3}{*}{ Risk factors } & \multicolumn{4}{|c|}{ Severity of preeclampsia } & \multirow{3}{*}{$\begin{array}{c}p- \\
\text { value }\end{array}$} \\
\hline & \multicolumn{2}{|c|}{$\begin{array}{c}\text { Mild } \\
(\mathrm{n}=88)\end{array}$} & \multicolumn{2}{|c|}{$\begin{array}{l}\text { Severe } \\
(\mathrm{n}=57)\end{array}$} & & & \multicolumn{2}{|c|}{$\begin{array}{l}\text { Mild } \\
(\mathrm{n}=88)\end{array}$} & \multicolumn{2}{|c|}{$\begin{array}{l}\text { Severe } \\
(\mathrm{n}=57)\end{array}$} & \\
\hline & No. & $\%$ & No. & $\%$ & & & No. & $\%$ & No. & $\%$ & \\
\hline Gravidity: & & & & & & History of essential & & & & & \\
\hline Primigravida & 54 & 62.1 & 33 & 37.9 & 0.732 & $\begin{array}{l}\text { Hypertension: } \\
\text { Yes }\end{array}$ & 1 & 25.0 & 3 & 75.0 & 0.300 \\
\hline $2-3$ & 20 & 62.5 & 12 & 37.5 & & No & 87 & 61.7 & 54 & 38.3 & \\
\hline$>3$ & 14 & 53.8 & 12 & 46.2 & & $\begin{array}{l}\text { Previous history of } \\
\text { preeclampsia: }\end{array}$ & & & & & \\
\hline Parity: & & & & & & Yes & 8 & 42.1 & 11 & 57.9 & 0.075 \\
\hline Nullipara & 54 & 62.1 & 33 & 37.9 & 0.741 & No & 80 & 63.5 & 46 & 36.5 & \\
\hline $1-2$ & 24 & 61.5 & 15 & 38.5 & & $\begin{array}{l}\text { History of diabetes } \\
\text { mellitus: }\end{array}$ & & & & & \\
\hline$>2$ & 10 & 52.6 & 9 & 47.4 & & $\begin{array}{l}\text { Yes } \\
\text { No }\end{array}$ & $\begin{array}{l}4 \\
84\end{array}$ & $\begin{array}{l}44.4 \\
61.8\end{array}$ & $\begin{array}{l}5 \\
52\end{array}$ & $\begin{array}{l}55.6 \\
38.2\end{array}$ & 0.316 \\
\hline Abortion: & & & & & & History of & & & & & \\
\hline No abortion & 75 & 59.5 & 51 & 40.5 & 0.459 & $\begin{array}{l}\text { bronchial asthma: } \\
\text { Yes }\end{array}$ & 0 & 0.0 & 5 & 100.0 & $0.008^{*}$ \\
\hline Abortion & 13 & 68.4 & 6 & 31.6 & & No & 88 & 62.9 & 52 & 37.1 & \\
\hline
\end{tabular}


Table (9): Relationship between severity of preeclampsia and level of socioeconomic status.

\begin{tabular}{lcccccc}
\hline \multirow{2}{*}{$\begin{array}{l}\text { Level of } \\
\text { Socioeconomic } \\
\text { status }\end{array}$} & \multicolumn{3}{c}{ Severity of preeclampsia } & \\
\cline { 2 - 3 } & Mild (n=88) & & \multicolumn{2}{c}{ Severe $(\mathrm{n}=57)$} & $\begin{array}{c}p \text { - } \\
\text { value }\end{array}$ \\
\cline { 2 - 3 } & No. & $\%$ & & No. & $\%$ & \\
\hline Very low & 16 & 47.1 & & 18 & 52.9 & 0.085 \\
Low & 20 & 55.6 & & 16 & 44.4 & \\
Middle & 24 & 63.2 & & 14 & 36.8 & \\
High & 28 & 75.7 & 9 & 24.3 & \\
\hline
\end{tabular}

Table (10): Score of socioeconomic status according to severity of preeclampsia.

\begin{tabular}{|c|c|c|c|}
\hline \multirow{2}{*}{$\begin{array}{l}\text { Score of } \\
\text { socioeconomic } \\
\text { status }\end{array}$} & \multicolumn{2}{|c|}{ Severity of preeclampsia } & \multirow{2}{*}{$\begin{array}{c}p- \\
\text { value }\end{array}$} \\
\hline & $\begin{array}{c}\text { Mild } \\
\text { Mean } \pm \text { SD }\end{array}$ & $\begin{array}{c}\text { Severe } \\
\text { Mean } \pm \text { SD }\end{array}$ & \\
\hline Education & $17.17 \pm 7.19$ & $14.35 \pm 7.20$ & $0.024 *$ \\
\hline Occupation & $4.21 \pm 3.41$ & $3.33 \pm 3.00$ & 0.111 \\
\hline Family possessions & $4.47 \pm 1.85$ & $3.60 \pm 1.70$ & $0.005^{*}$ \\
\hline Family & $4.81 \pm 1.07$ & $4.54 \pm 0.85$ & 0.161 \\
\hline Home sanitation & $6.71 \pm 2.00$ & $5.84 \pm 2.01$ & $0.014^{*}$ \\
\hline Economic & $1.52 \pm 1.12$ & $1.11 \pm 1.03$ & $0.030^{*}$ \\
\hline Healthcare & $3.42 \pm 1.25$ & $3.12 \pm 1.05$ & 0.217 \\
\hline Total score & $42.30 \pm 15.73$ & $35.90 \pm 14.52$ & $0.012 *$ \\
\hline
\end{tabular}

\section{Discussion}

The present study showed an association between age of the mother and SES of the family; the less the socioeconomic status of the case, the lower would be the age. Also the rate of preeclampsia more common in younger age group especially those below age of 25 years old and the rate decline with increase of age; but there was no statistical significant relationship between age and severity of preeclampsia. this study agreed with DirekvandMoghadam et al., [16] \& Ganesh et al., [17]. They all revealed that there was no significant relationship between the maternal age and preeclampsia.

Contradictory, Ramesh et al., [18] revealed that age of less than 20 years is found to be of significant risk factor of preeclampsia. Also Carty, [19] considered that women who went on to develop PE were younger than those who did not develop the condition.

On the other hand; Bilano et al., [20] \& Sekkarie et al., [21] reported that increased age is associated with an increased risk of preeclampsia.

Concerning to the gestational age, the present study shows a significant relation between gestational age and severity of PE. These findings agreed with Carty, [19] who confirmed that women who developed preeclampsia were more likely to have delivered at an earlier gestation and to have smaller babies.

As regard to education of the parents, the present study showed a statistical significant relationship between education and preeclampsia and its severity. preeclampsia is more common and more severe in women with low education level. So low education is considered a risk factor for preeclampsia. This study is agreed with Abubakar Attahir et al., [22] \& Gahwai and Badgaiyan., [23] all revealed that preeclampsia was more common among the mother who had low level of education. So Significant association found between the toxemia of pregnancy and level of education of mothers.

Conversely, a study by El-Moselhy et al., [24] demonstrated that low educational level (illiterates, and read and write) of the cases was insignificant risk factor.

As regard occupation, the present study showed no difference between incidence of preeclampsia in non working women compared to women with physical or stressful work. this agreed with study by Nugteren et al., [25] \& El-Nakhal., [26] that concluded no statistical relationship between maternal occupation and preeclampsia development.

Contradictory, findings have been reported by Mozurkewich et al., [27] showed that a metaanalysis, based on 4 studies, that physically demanding work was significantly associated with PIH and preeclampsia. Also Haelterman et al., [28] suggested that being exposed to physically demanding and stressful occupational conditions at the onset of pregnancy increases the risk of preeclampsia.

Concerning to the economic domain which represent the family income, the present study illustrated that rate of preeclampsia is common in women with low income and severity of preeclampsia increase by decrease of the income. This results agreed with Fadia, [29] \& Mujawar and Patil, [30] study.

As regard to gravidity, the rate of preeclampsia is higher in primigravida and the rate decrease with increase gravidity. The study agreed with ElNakhal, [26] \& Guerrier et al., [31] \& El-Moselhy et al., [24] which revealed that being primigravida is a risk factor that increased the risk of development of PE.

Conversely, a study by Abubakar Attahir et al., [22] showed that parity is negatively correlated with preeclampsia. 
As regard to abortion, the present study found no association between abortion in first trimester and preeclampsia. Our findings agreed with ElMoselhy et al., [24] which resulted that abortion in first trimester are insignificant risk factors. While a study conducted by Parker et al., [32] \& Trogstad et al., [33] observed that there is a slightly reduced risk of preeclampsia in women with one induced abortion, as compared with women without induced abortions. Conversely, another study by Xiong et al., [34] reported an increasing risk of PE with an increasing number of abortions.

The present study showed no significant statistical relationship between previous history of preeclampsia and severity of preeclampsia in the current pregnancy. Which agreed with a study by ElMoselhy et al., [24] which showed that history of prior PE/eclampsia is insignificant risk factors. Contradictory, a study by Direkvand-Moghadam et al., [16] showed that there is significant association between preeclampsia and history of PE, and considered that history of PE was the most important variable to predict PE.

A strong relationship between the history of $\mathrm{PE}$ and recurrence risk of PE has been reported by many researches El-Nakhal, [26] \& Mostello et al., [35].

The present study shows no relationship between history of essential hypertension and PE. this agreed with a study by Abu baker Attahir et al., [22] which showed that history of hypertension are negatively correlated with PE. Conversely, a study by Direkvand-Moghadam et al., [16] \& Duckitt \& Harrington, [36] showed a significant association between preeclampsia and history of hypertension.

As Regard to diabetes mellitus; the present study showed no statistical significant difference between diabetes mellitus and preeclampsia. While in a study by El-Nakhal, [26]; diabetes mellitus is a risk factor that increased the risk of development of PE. The effect of diabetes on preeclampsia studied by many studies El-Moselhy et al., [24] \& Roberts and Cooper, [37]. They all revealed that diabetes is an important risk factor for preeclampsia.

The present study showed a statistical significant association between bronchial asthma and preeclampsia. Which agreed with Rejnö et al., [38] $\&$ Mendola et al., [39] studies. They resulted in there was an association between maternal asthma and increased risks of preeclampsia or eclampsia. Many other studies Breton et al., [40] \& Tamasi et al., [41] considered that Bronchial asthma is a risk factor for PE and gestational hypertension.

The present study shows an association between family possessions and PE and between home sanitation domain including services (water supply, electricity, natural gas and sewerage system. etc.), type of house and crowding index and PE. There is no association between health care and preeclampsia.

Also the study shows no relationship between levels of SES and incidence of PE but there is an association between total score of SES and severity of PE; PE is severe in low socio-economic class than high socioeconomic class.

A study by El-Moselhy et al., [24] revealed that As regard socio-demographic risk factors of the PE cases and controls. Collectively, $59.0 \%$ of the patients were belonged to lower social level and represented a significant risk factor. On the other hand, middle social level is significant protective factors. Also Guerrier et al., [31] revealed that low socio-educational status was strongly associated with PE/eclampsia. Conversely, a study by Tanaka et al., [42] have found socioeconomic circumstances to be negatively associated with preeclampsia.

\section{Limitations of the study:}

Some limitations should however be pointed out:

- The low socioeconomic level of the government where the study was conducted.

- Some may argued that occupational classification systems differentiate more poorly between women's jobs, and that studies of socioeconomic level based on occupation will underestimate the level of SES of the women.

- Regarding the association between socioeconomic variables, our results may reflect some problems of statistical power, due to the small number of participants in the study.

\section{Conclusion:}

Based on the results of the present study, it can be concluded that low educational level of the parents, poor home sanitation, low family possessions, and low economic status are risk factors for PE. Also low gestational age and bronchial asthma are associated with severe PE. But there is no relationship between severity of $\mathrm{PE}$ and mother age, obstetric history, previous history of PE, medical diseases such as essential hypertension and diabetes mellitus, occupation of the parents, family domain and health care domain. 


\section{References}

1- MAYER S.E. and JENCKS C.: Growing up in poor neighborhoods: How much does it matter? Science, 243: 1441-5, 1989 .

2- BRAVEMAN P.A., et al.: Socioeconomic status in health research: One size does not fit all. Journal of the American Medical Association, 294: 2879-88, 2005.

3- MORRIS S., C. CARLETTO, J. HODDINOTT and L.J. CHRISTIANSEN: "Validity of Rapid Estimates of Household Wealth and Income for Health surveys in Rural Africa." Journal of Epidemiology and Community Health, 54: 381-87, 2000.

4- OAKES J. and P. ROSSI: "The measurement of Socioeconomic status in health Research: Current Practices and Steps Towards a New Approach. "Social science and medicine, 53: 769-84, 2003.

5- DUNCAN D., M. DALY, P. McDONOUGH and D.R. WILLIAMS: "Optimal Indicators of SES for health Research." American Journal of Public Health, 92 (7): 11517, 2002.

6- GUPTA P. and GHAI O.P.: Textbook of preventive and social medicine, 2 nd ed. New Delhi, CBS Publishers and Distributors, 626, 2007.

7- SPENSER J., POLAVARAPU S., TIMMS D., et al.: Regional and monthly variation in rates of preeclampsia at delivery among U.S. births Abstract No 294. Presented at the 29th annual meeting of the society for MaternalFetal Medicine, January, 26-31, 2009.

8- SCHOLTEN R.R., HOPMAN M.T., SWEEP F.C., et al. Co-occurrence of cardiovascular and prothrombotic risk factor in women with a history of preeclampsia. Obstet. Gynecol., 121 (1): 97, 2013.

9- WAGNER L.K.: Diagnosis and management of preeclampsia. Am. Fam. Physician. Des., 70 (12): 2317-24, 2004.

10- CANTWELL R., CLUTTON-BROCK, et al.: Saving mothers' lives: Reviewing maternal deaths to make motherhood safer: 2006-2008. The Eighth Report of the Confidential Enquiries in to Maternal Deaths in the United Kingdom, B.J.O.G., 118 (Suppl 1): 1-203, 2011.

11- LEWIS G. (ed.): The confidential Enquiry in to Maternal and Child health (CEMACH). Saving mothers' lives: Reviewing maternal deaths to make motherhood safer2003-2005. The Seventh Report on Confidential Enquiries in to Maternal Deaths in the United Kingdom. London: CEMACH, 2007.

12- Task Force: Hypertension in pregnancy. Report of the American college of Obstetri-cians and Gynecologists-Task Force on Hypertension in pregnancy. Obstet. Gynecol., 122: 1122, 2013.

13- SIABI B.M. and STELLA C.L.: Diagnosis and management of atypical preeclampsia-eclampsia. Am. J. Obstet. Gynecol., 200: 481.el, 2009.

14- Hypertension in pregnancy. The management of hypertensive disorders during pregnancy, Naional Institute for Healh and Excellence Clinical Guide Line, 107, 2010.

15- BLACKWELL S.C., REDMAN M.E., et al.: Labor induction for he preterm severe pre-eclamptic patient: Is it work the effort? J. Matern. Fetal. Med., 10: 305-11, 2001.
16- DIREKVAND-MOGHADAM A., KHOSRAVI A. and SAYEHMIRI K.: Predictive factors for pre-eclampsia in pregnant women: A unvariate and multivariate logistic regression analysis. Acta Biochim. Pol., 59 (4): 673-7, 2012.

17- GANESH K.S., UNNIKRISHNAN B., et al.: Determinants of preeclampsia: A case-control study in a district hospital in South India. Indian J. Community Med., 35: 502-5, 2010.

18- RAMESH K., SANGEETHA GANDHI and VISHWAS RAO: Socio-Demographic and Other Risk Factors of Pre Eclampsia at a Tertiary Care Hospital, Karnataka: Case Control Study. J. Clin. Diagn. Res., Sep., 8 (9): JC01JC04, 2014.

19- CARTY D.M.: Pre-eclampsia; early prediction and longterm consequences, 2012.

20- BILANO V.L., OTA E., GANCHIMEG T., MORI R. and SOUZA J.P.: Risk Factors of Pre-Eclampsia/Eclampsia and Its Adverse Outcomes in Low-and Middle-Income Countries: A WHO Secondary Analysis. PLoS ONE, 9 (3): e91198, 2014.

21- AHLIA SEKKARIE, CHERYL RASKIND-HOOD and CAROL HOGUE: The effects of maternal weight and age on pre-eclampsia and eclampsia in Haiti. The Journal of Maternal-Fetal \& Neonatal Medicine, Volume 29, Issue 4, 2016.

22- ABUBAKAR ATTAHIR, A.A.U. DIKKO, M.B. SUFIYAN, ALIYU SALIHU and A.M. RABIU: Association between Maternal Socio-economic Status, Polygamy and Risk of Pre-eclampsia in Rural Areas of Northern Nigeria: Journal of Family and Reproductive Health, Vol. 4, No. 1, March: 47-52, 2010.

23- GAHWAI D.K. and BADGAIYAN Y.D.: Socioeconomic Maternal Risk Factors for Toxemia of Pregnancy: A CrossSectional Study in A tertiary Care Hospital of Chhattisgarh. IJSR-International Journal Of Scientific Research. July Volume: 5, Issue: 7, 2016.

24- ESSAM A. EL-MOSELHY, HAMED O. KHALIFA, SOLIMAN M. AMER, KHADRA I. MOHAMMAD and HANI M. ABD EL-AAL: Risk Factors and Impacts of Pre-Eclampsia: An Epidemiolo-gical Study among Pregnant Mothers in Cairo, Egypt. Journal of American Science, 7 (5): 311-23. (ISSN: 1545-1003), 2011.

25- NUGTEREN J.J., SNIJDER C.A., HOFMAN A., JADDOE V.W.V., et al.: Work-Related Maternal Risk Factors and the Risk of Pregnancy Induced Hypertension and Preeclampsia during Pregnancy. The Generation R Study. PLoS ONE, 7 (6): e39263, 2012.

26- EL-NAKHAL S.: Case-control study of risk factors associated with preeclampsia in the Gaza Strip: Journal of Medicine and Medical Sciences, Vol. 6 (9) pp. 22933, 2015.

27- MOZURKEWICH E.L., LUKE B., AVNI M. and WOLF F.M.: Working conditions and adverse pregnancy outcome: A meta-analysis. Obstet. Gynecol., 95: 623-35, 2000.

28- HAELTERMAN E., MARCOUX S., CROTEAU A., et al.: Populationbased study on occupational risk factors for preeclampsia and gestational hypertension. Scand J. Work Environ Health, 33: 304-17, 2007. 
29- FADIA RHYTHM M., M.S.: Effect of preeclampsia on pregnancy and impact of age, race and income on preeclampsia. By California State University, Long Beach, 42 pages; 1504455, 2011

30- SHAHID A. MUJAWAR and VINAYAK W. PATIL: Socio-economic characteristics and pregnancy induced hypertension in the women of western region of India. Internat. J. Med. Sci., 3 (1 \& 2): 24-6, 2010.

31- GUERRIER G., OLUYIDE B., KERAMROU M. and GRAIS R.: Factors associated with severe preeclampsia and eclampsia in Jahun, Nigeria: International Jornal of Women S Health, 5: 509-13, 2013.

32- PARKER S.E., GISSLER M., et al.: Induced Abortions and the Risk of Preeclampsia Among Nulliparous Women: Am. J. Epidemiol., Oct. 15, 182 (8): 663-9, 2015.

33- TROGSTAD L., MAGNUS P., SKJÆRVEN R., et al.: Previous abortions and risk of pre-eclampsia. Int. J. Epidemiol., 376: 1333-40, 2008.

34- XIONG X., FRASER W.D. and DEMIANCZUK N.N.: History of abortion, preterm, term birth, and risk of preeclampsia: A population-based study. Am. J. Obstet. Gynecol., 1874: 1013-8, 2002.

35- MOSTELLO D., KALLOGJERI D., TUNGSIRIPAT R. and LEET T.: Recurrence of preeclampsia: Effects of gestational age at delivery of the first pregnancy, body mass index, paternity, and interval between births. Am. J. Obstet. Gynecol., 199: 55 e1-e7, 2008.
36- DUCKITT K. and HARRINGTON D.: Risk factors for preeclampsia at antenatal booking: Systematic review of controlled studies. B.M.J., 330: 565-7, 2005.

37- ROBERTS J.M. and COOPER D.W.: Pathogenesis and genetics of pre-eclampsia. Lancet, 357: 53-6, 2001.

38- REJNÖ G., LUNDHOLM C., GONG T., LARSSON K. SALTVEDT S. and ALMQVIST C.: Asthma during Pregnancy in a Population-Based Study-Pregnancy Complications and Adverse Perinatal Outcomes: PLoS One, 9 (8): e104755, 2014.

39- MENDOLA P., LAUGHON S.K., MANNISTO T.I., LEISHEAR K., et al.: Obstetric complications among US women with asthma. Am. J. Obstet. Gynecol., 208: e1e8, 2013.

40- BRETON M.C., BEAUCHESNE M.F., LEMIÈRE C., REY E., FORGET A., et al.: Risk of perinatal mortality associated with asthma during pregnancy. Thorax, 64: 101-6, 2009.

41- TAMASI L., SOMOSKOVI A., MULLER V., BARTFAI Z., ACS N., PUHO E. and CZEIZEL A.E.: A populationbased case-control study on the effect of bronchial asthma during pregnancy for congenital abnormalities of the offspring. J. Asthma, 43: 81-6, 2006.

42- TANAKA M., JAAMAA G., KAISER M., et al.: Racial disparity in hypertensive disorders of pregnancy in New York State: A 10-year longitudinal population-based study. Am. J. Public Health, 97 (1): 163-70, 2007.

\section{دراسة تآثير مقياس مستوى الحالة الإجتماهية والإقتتصادية على تسمى الحمل مالحمل}

\footnotetext{
يعرف تسمم الحمل بآثه متلازمة خاصة بالحمل ويحدث عادة بعد الإسببوع العشرين من الحمل، والذى يحدد بإرتفاع ضغط الدم الإنقباضى

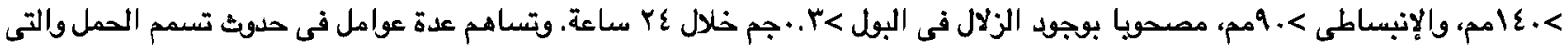

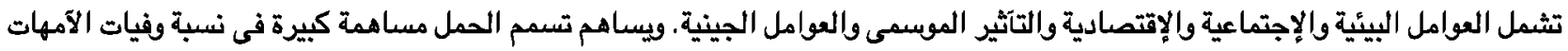

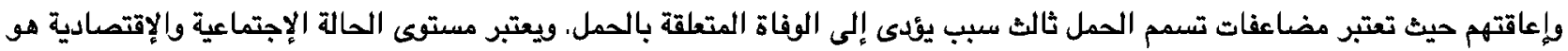

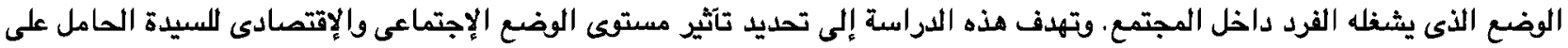

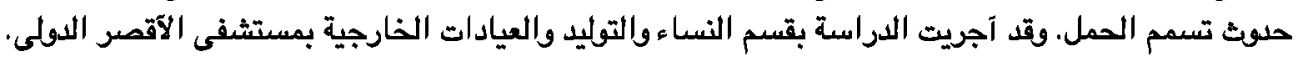

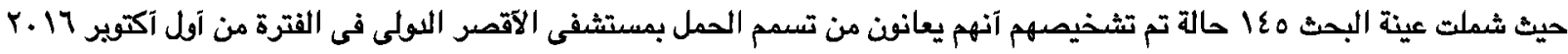

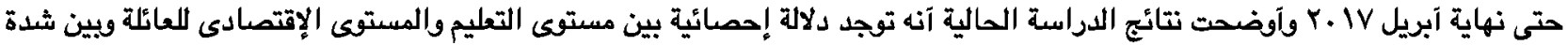
تسمم الحمل. وعلى ضوى نتائج الدراسية يمكن إستخلاص التولئ التوصيات التالية: ا- تحسين المستوى التعليمى في المجتمعات الريفية.

Y- ينبفى تنظيم برامج التثقيف الصحى للسيدات الحوامل عن العوامل المؤدية إلى تسمم الحمل وكذلك لطاقم العمل عن العوامل المؤدية

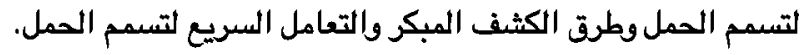
ب- يتم فحص كل الحوامل عند آول زيارة وعلى فترات معينة للبحث عن آعراض وعلامات لتسمم الحمل. ع- يمكن إستخدام العوامل المساعدة لحدوث تسمم الحمل كمقياس للتبؤ بحدوث المرض. ه- تصسين المستوى الصحى للآسر الريفية الفقيرة للحد من المشاكل والمخاطر الصحية المئدية إلى إهدار حياة الآم والجنين والتى تمثل

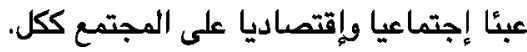

